Ks. Augustyn ECKMANN

(Lublin, KUL)

\title{
ZNACZENIE PETRA (MT 16, 18) W INTERPRETACJI ŚWIĘTEGO AUGUSTYNA
}

Św. Augustyn wyjaśniając perykopę ewangeliczną Mt 16, 13-23: wyznanie św. Piotra w okolicach Cezarei Filipowej, 28 razy przytacza jej zdanie: „tu es Petrus, et super hanc petram aedificabo Ecclesiam meam" $(16,18)$, w tym raz zmieniając wyrażenie „Ecclesiam meam na fidem”, a więc: „,super hanc petram aedificabo fidem, quam confiteris" ". W wybranych augustyńskich tekstach spróbuję określić, jakie znaczenie ten Biskup w różnych swych pismach nadawał rzeczownikowi ,petra”.

1. Petra - Chrystus. Augustyn komentując zdanie św. Pawła, nawiązujące do przykładu z dziejów Izraela, o jego przejściu przez morze, konkluduje:

„«Wszyscy też spożywali ten sam pokarm duchowy i pili ten sam duchowy napój. Pili zaś z towarzyszącej im duchowej skały, a ta skała - to był Chrystus» (1 Kor 10, 3-4), na którym to fundamencie Piotr jest zbudowany, «bo nikt nie może założyć innego fundamentu, prócz tego, który jest już założony, a którym jest Jezus Chrystus» $(1$ Kor 3,11$) "$ ?

Kościół, który jest zbudowany na Chrystusie, otrzymał od Niego w Piotrze władzę wiązania i rozwiązywania spraw sumienia. Czym jest we właściwym znaczeniu Kościół w Chrystusie, tym symbolicznie Piotr w skale. Z kolei Chrystusa jako skałę należy rozumieć symbolicznie, podobnie Piotra jako Kościół. Augustyn używa tu metafory, która wyraża pewne podobieństwo Piotra z Chrystusem: Piotr został nazwany skałą ze względu na moc i siłę wiary, a skałą jest Chrystus. Zauważmy, że te wyrażenia są metaforami. Sam zresztą Augustyn przestrzega przed dosłowną interpretacją terminów stosowanych do Chrystusa, takich jak: brama, kamień węgielny, pasterz, lew, baranek, skała, itp.: wszystkie bowiem są tylko przenośniami ${ }^{3}$.

\footnotetext{
1 Sermo 295, 1, 1, NBA (= Nuova Biblioteca Agostiniana) 33, 310.

2 Por. In Johannis Evangelium tractatus 124, 5, NBA 24/2, 1618, thum. W. Szołdrski, PSP 15/2, 374.

${ }^{3}$ Por. In Johannis Evangelium tractatus 47, 6.
} 
W Retractationes Augustyn ocenia zaginione swoje antydonatystyczne dzieło Contra epistolam Donati haeretici pisząc:

„Tam to w pewnym miejscu powiedziałem o apostole Piotrze, «że na nim, niczym na skale założony został Kościół». To samo śpiewają usta wielu w poezji świętego Ambrożego o kogucie: «kiedy on pieje - ta skała Kościoła, winy rozwieje» ${ }^{4}$. [...]. Pamiętam jednak, że później bardzo często wyjaśniałem słowa wypowiedziane przez Pana ${ }^{5}$ : «Ty jesteś Piotr (czyli skała), i na tej skale zbuduję mój Kościół», rozumiejąc tak, aby myślano, iż Kościół został zbudowany na Tym, w którego wiarę Piotr wyraził słowami: «Ty jesteś Mesjasz, Syn Boga żywego», a Piotr tak nazwany przez ową Skałę reprezentował sobą cały Kościół, który wznosi się na tej Skale i «otrzymał klucze królestwa niebieskiego». Albowiem nie powiedziano mu: «ty jesteś skała», lecz ty jesteś Piotr, Skałą zaś był Chrystus (Mt 16, 18; J 1, 42; 6, 69; 1Kor 10, 4), którego wyznał Szymon zwany Piotrem, jak to zresztą cały Kościół wyznaje. Który z tych poglądów jest bardziej prawdopodobny, niech wybiera sam czytelnik" $"$.

Biskup Hippony dopuszcza tu więc obie interpretacje. Czytelnik ma sam wybrać pogląd, który uważa za bardziej prawdopodobny: czy skałą jest Chrystus, czy Piotr. Przemawia to za tym, że Augustyn interpretując termin „,petra”, raczej nie przywiązywał większej wagi do jego teologicznego znaczenia.

Kiedy jednak w sporze z donatystami wyjaśniał przynależenie do Kościoła, wówczas budowę Kościoła łączył z przypowieścią o domach - zbudowanym na skale i zbudowanym na piasku. Podkreślał wtedy, że skała jest jedna, a dwukrotnie przytaczany urywek z 1 Kor 10, 4: ,a skałą był Chrystus”, pozwalał mu ją utożsamiać z Chrystusem ${ }^{7}$. Na tej skale znajdują się ci, którzy tworzą Kościół słuchający słów Chrystusa i wprowadzający je w życie. Ten Kościół nie ogranicza się do Afryki, ale jest katolicki, to znaczy rozsiany po całym świecie ${ }^{8}$, rozciąga się z woli Chrystusa aż po krańce świata. Biskup Hippony, powołując

${ }^{4}$ Ambrosius, Hymnus I; zob. Hexaemeron V 24, 88.

Por. Augustinus, Sermo 76, 1, 1, NBA 30/1, 514.

${ }^{6}$ Retractationes 20, 2, NBA 2, 114; tłum. J. Sulowski, PSP 22, 230.

7 Por. De sermone Domini in monte II 87, NBA 10/2, 282: „Et si petra est Christus, sicut multa Scripturarum testimonia praedicant, ille aedificat in Christo qui quod ab illo audit, facit"; In Johannis Evangelium tractatus 47, 6, NBA 24/2, 938: „Per similitudinem et petra est Christus, et ostium est Christus, et lapis angularis est Christus, et pastor est Christus, et agnus est Christus, et leo est Christus".

${ }^{8}$ Por. A. Eckmann, Dialog świętego Augustyna ze światem pogańskim w świetle jego korespondencji, Lublin 1987, 212; zob. Augustinus, Contra litteras Petiliani II 108, 247, CSEL 52, 159160: ,illa quippe Ecclesia in petra est, sicut Dominus dicit: «super hanc petram aedificabo Ecclesiam meam»; illi autem in harena aedificant, sicut idem Dominus dicit: «qui audit verba mea et non facit ea, simulabo eum viro stulto qui aedificat domum suam super harenam» [...]. Videte quemadmodum in petra exaltetur; non ergo in ea deputandi sunt omnes qui aedificant in harena, id est qui audiunt verba Christi et non faciunt; qui tamen et apud nos et apud vos habent et tradunt baptismi sacramentum; Contra Gaudentium 2, 2, NBA 16/2, 522, 524. 
się na 1Kor 1, 12-13 nieustannie powtarzał donatystom, iż Kościół nie opiera się na ludziach, ale na Chrystusie. Tak na przykład w mowie 76 mówi wyraźnie, że On jest skałą, a Piotra utożsamia z ludem chrześcijańskim:

„Ty jesteś, mówi, Piotrem; i na tej skale, którą wyznałeś publicznie, na tej skale, którą rozpoznałeś jako prawdziwą, mówiąc: «Ty jesteś Chrystusem, Synem Boga żywego, zbuduję mój Kościół» (Mt 16, 18). To znaczy: na mnie samym Synu Boga żywego zbuduję mój Kościół. Na mnie zbuduję Ciebie, nie mnie na tobie""9.

Chrystus zbuduje Kościół na sobie samym, jako na Synu Boga żyjącego, zbuduje swój Kościół. W świetle 1Kor 10, 4 „skałę” utożsamia Augustyn z Chrystusem. Na tej skale znajdują się ci, którzy tworzą Kościół, słuchający słów Chrystusa i wprowadzający je w życie. Ten Kościół nie ogranicza się do Afryki, ale rozciąga się z woli Chrystusa na cały świat, stąd Augustyńskie odwołanie się do Psalmu 60, który jest prawdziwym hymnem antydonatystycznym:

„Od krańców ziemi wołałem do ciebie, kiedy serce moje doznawało niepokoju (Ps $60,3)[\ldots]$ tu rozpoznajemy, kto woła krańców ziemi. Wspominamy Ewangelię. «Na tej skale zbuduję mój Kościół» (Mt 16, 18). Ten więc woła z krańców ziemi, który zapragnął być zbudowanym na skale. Kto więc stał się skałą, aby można było zbudować Kościół na ziemi? Posłuchaj Pawła, który mówi: «Skałą zaś był Chrystus» $(1$ Kor 10,4$), 10$.

Na Chrystusie - skale - zostaliśmy zbudowani.

Również w mowie poświęconej jedności chrześcijan, pokojowi i miłości, w kontekście Mt 16, 18: „na tej skale zbuduję mój Kościół, a bramy piekielne go nie zwyciężą", podkreśla, że skałą był Chrystus:

"«Skałą zaś był Chrystus». A może Paweł za nas został ukrzyżowany? Trzymajcie się tych rzeczy, kochajcie te rzeczy, mówcie o nich między sobą w pokoju"11.

W uroczystość apostołów Piotra i Pawła Biskup Hippony nauczał, że Chrystus na skale zbudował wiarę, którą Piotr wyznał i na jego wyznaniu: „Ty jesteś

${ }^{9}$ Sermo 76, 1, NBA 30/1, 514: „Tu es, inquit, Petrus; et super hanc petram quam confessus es, super hanc petram quam cognovisti, dicens: Tu es Christus Filius Dei vivi, aedificabo Ecclesiam meam (Mt 16,18); id est: Super me ipsum Filium Dei vivi, aedificabo Ecclesiam meam. Super me aedificabo te, non me super te".

${ }^{10}$ Enarratio in Psalmum 60, 3 NBA 26, 326: „A finibus terrae ad te clamavi, dum angeretur cor meum (Ps 60,3) [...] hic agnoscimus quis clamet a finibus terrae. Recolamus Evangelium: «Super hanc petram aedificabo Ecclesiam meam» (Mt 16, 18). Ergo illa clamat a finibus terrae, quam voluit aedificari super petram. Ut autem aedificaretur Ecclesia super terram, quis factus est petra? Paulo audi docente: «Petra autem erat Christus»".

11 Sermo 358, 5, NBA 34, 294: „«Petra autem erat Chrystus». Numquid Paulus pro vobis crucifixus est? (1Kor 10,4). Haec tenete, haec amate, haec fraterne et pacifice dicite". 
Chrystus Syn Boga żywego", zbudował Kościół. Nawiązując zaś do 1Kor 10, $1-4$, wołał, że ojcowie pili z towarzyszącej im skały, a był nią Chrystus ${ }^{12}$.

W ostatniej Homilii do Ewangelii św. Jana Augustyn daje wyrazisty obraz powołania św. Piotra. W antytezie między powołaniem Jana i Piotra przedstawia rolę, jaką mieli do spełnienia ci dwaj apostołowie. Misja Piotra polega na wcieleniu Kościoła w czas, ma uczynić Kościół pielgrzymującym, żyjącym wiarą, który dzięki tej wierze działać będzie przez miłość. Piotr wyznaniem wiary w bóstwo Chrystusa zasłużył sobie na miano drugorzędnego fundamentu, bo pierwszorzędnym jest Chrystus: „,bo nikt nie może założyć innego fundamentu, prócz tego, który jest już założony, a którym jest Chrystus Jezus (1Kor 3, 11)"13:

„I ja mówię tobie, ponieważ ty wpierw mi powiedziałeś; ty powiedziałeś, teraz słuchaj: uczyniłeś wyznanie wiary, teraz przyjmij błogosławieństwo. Dlatego ja mówię tobie: ty jesteś Piotrem; ponieważ ja jestem skałą, ty jesteś Piotrem. Skała nie pochodzi od Piotra, lecz Piotr pochodzi od skały, jak Chrystus nie pochodzi od chrześcijanina, lecz chrześcijanin od Chrystusa. «I na tej skale zbuduję mój Kościół» (Mt 16, 18), nie na Piotrze, czym ty jesteś, lecz na skale, którą wyznałeś. Zbuduję mój Kościół, zbuduję ciebie, który w tej odpowiedzi wyobrażasz Kościół"14.

Święty Augustyn, wyjaśniając wiersz Mt 16, 18, idzie za myślą św. Pawła. Kościół jest zbudowany na skale (petra), w którą swą wiarę wyznał Piotr. W nagrodę za wyznanie otrzymał władzę kluczy i nowe imię Petrus jako przedstawiciel Kościoła. Skałą - petra, którą św. Piotr wyznał i od której otrzymał imię, jest Chrystus.

2. Petra - Piotr. Kilka razy przez termin petra rozumie św. Augustyn osobę Piotra. W napisanym pod koniec 394 roku lub na początku 395 Psalmus contra partem Donati czytamy:

„Venite fratres, si vultis, ut inseramini in vite,

Dolor est cum vos videmus praecisos ita iacere

Numerate sacerdotes vel ab ipsa Petri sede

et in ordine illo patrum quis cui successit videte:

ipsa est petra quam non vincunt superbae inferorum portae" 15 .

12 Por. Sermo 295, 1, 1, NBA 33, 310: „Super hanc petram aedificabo fidem, quam confiteris [...]. Bibebant enim de spiritali sequente eos petra; petra autem erat Christus. Ecce unde Petrus.

13 Por. In Iohannis Evangelium tractatus 124, 5, NBA 24/2, 1618, PSP 15, 374.

14 Sermo 270, 2, NBA 32/2, 1024: ,Et ego dico tibi, quia tu dixisti mihi; dixisti, audi; dedisti confessionem, recipe benedictionem; ergo: Et ego dico tibi: tu es Petrus; quia ego petra, tu Petrus; neque enim a Petro petra, sed a petra Petrus, quia non a christiano Christus, sed a Christo christianus. «Et super hanc petram aedifico Ecclesiam meam» (Mt 16, 18), non supra Petrum quod tu es; sed supra petram, quam confessus es. Aedifico autem Ecclesiam meam; aedificabo te, qui in hac responsione figuram gestas Ecclesiae".

${ }_{15}$ Psalmus contra partem Donati 236-244, NBA 15/1, 36, przekład własny: „Przyjdźcie, bracia, jeśli chcecie, abyście wszczepili się w winną latorośl. Jest bolesne, kiedy widzimy was, jak odcięci 
„Sedes Petri” jest odpowiednikiem „Petrus”, a ten jest „petra”.

Drugi analogiczny tekst występuje u św. Augustyna w cytowanych wyżej Retractationes, przy omawianiu zaginionego listu Contra Epistulam Donati haeretici, napisanego prawdopodobnie w 394 r., z powołaniem się na św. Ambrożego (nie zachował się ani list Donata, ani odpowiedź Augustyna):

„In quo dixi quodam loco de apostolo Petro, quo «in illo tamquam in petra fundata sit Ecclesia»" $" 16$.

W liście zatem św. Augustyna do Donata Piotr został nazwany skałą, na której Chrystus zbudował swój Kościół.

Trzeci tego rozdaju tekst znajduje się w traktacie De agone Christiano, napisanym około 396 r., dla umocnienia chrześcijan w wierze. Św. Augustyn przeciwstawiając się tym, którzy przeczą, że Kościół może odpuszczać wszystkie grzechy, pisze:

„Itaque miseri, dum in Petro petram non intellegunt et nolunt credere datas Ecclesiae claves regni coelorum, ipsi eas de manibus amiserunt"17.

Augustyn wskazuje na świętego Piotra, który powątpiewał na morzu (Mt 14, 30), odwodził Pana od męki (Mt 16, 22), trzy razy zaparł się Pana (Mt 26, 5, 7074) i popadł w przesadne udawanie (Ga 2,12), a mimo to Pan mu przebaczył i postawił na czele Kościoła (Mt 16, 19; J 21, 17). Stąd Kościół przyjmuje na swe macierzyńskie łono heretyków, którzy odwołują swoje błędne poglądy. Biskup Hippony przestrzega jednak przed tymi, którzy odmawiają Kościołowi władzy odpuszczania wszystkich grzechów. Godni pożałowania są ci, którzy nie rozpoznają w Piotrze skały i nie chcą wierzyć, że Kościół otrzymał władzę kluczy do Królestwa niebieskiego ${ }^{18}$.

W Enarrationes in Psalmos w kontekście objaśnień Psalmu 69, 4 o braku dobrej woli u tych, którzy przemyśliwują zło, Biskup Hippony mówi, iż tego należy życzyć obecnie prześladowcom obmyślającym zło, co Pan zawarł w słowach wypowiedzianych do Piotra. Kiedy bowiem Zbawiciel mówił o swojej męce, Piotr zapragnął Go wyprzedzić, usiłując odwieść od niej Jezusa. Gdyby jej Jezus nie przyjął, wyjaśnia Biskup, nie zostalibyśmy zbawieni:

„Piotr, który właśnie niedawno wyznał, że Jezus jest Synem Bożym, a podczas tego wyznania został nazwany skałą (Petra), na której zostanie zbudowany Kościół,

leżycie na ziemi. Policzcie biskupów począwszy od samej stolicy Piotra i w porządku ojców, widzicie, kto po nim nastąpił. To jest skała, której nie zwyciężą pyszne bramy piekła”.

16 Retractationes I 20, 1, NBA 2, 114, przekład własny: „W nim [w tym liście] powiedziałem w pewnym miejscu o apostole Piotrze, że na nim, jak na skale, został założony Kościół”.

17 De agone Christiano 31, 33, NBA7/2, 122, przekład własny: „Biedni bowiem, kiedy nie pojmują w Piotrze opoki, oraz nie chcą wierzyć we władzę kluczy danych Kościołowi i sami je z rąk utracili".

${ }^{18}$ Por. A. Eckmann, Symbol Apostolski w pismach świętego Augustyna, Lublin 1999, 122. 
(supra quam fabricaretur Ecclesia), nieco później, kiedy Pan mówił o swojej męce, powiada: «Broń cię Panie Boże. Żadną miarą nie przyjdzie to na ciebie». Niedawno usłyszał: «Błogosławiony jesteś, Szymonie, Bar Jona, bo nie ciało ani krew objawiły ci to, ale Ojciec mój, który jest w niebie» (Mt 16,17), a teraz nagle słyszy: «Idź za mną szatanie». Co znaczy: «Idź za mną»? Chcesz iść przodem, chcesz mi dawać rady, lepiej, żebyś szedł za moją radą. To jest: idź za mną, idź do tyłu”19.

Termin petra oznacza osobę Piotra. Określenie petra w dwóch wyżej przytoczonych tekstach, zwłaszcza w ostatnim, nie jest w pełni określeniem mocy, ale bardziej symbolem łaski. Piotr jest petra nie z powodu nieomylnej nauki, ale z powodu wiernego słuchania i naśladowania Słowa Bożego.

Wyraźne utożsamienie Piotra z petra odczytujemy w liście, napisanym najprawdopodobniej w latach 399-401, przez Augustyna, Alipiusza i Fortunata do Generozusa. Autorzy listu, chcąc udowodnić, że w spisie biskupów rzymskich nie ma żadnego donatysty, wymieniają ich, poprzedzając następującą uwagą:

„Jeżeli mamy rozważyć kolejność następujących po sobie biskupów, to o ileż pewniej i większym pożytkiem liczymy ich następstwo zaczynając od samego Piotra. Przecież to on symbolizował cały Kościół i do niego Pan powiedział: «Na tej skale zbuduję mój Kościół, a bramy piekielne go nie zwyciężą»” (Mt 16, 18) 20.

Po czym św. Augustyn wylicza następców św. Piotra, począwszy od Linusa, a skończywszy na Anastazym, stwierdzając, że w wymienionym porządku nie znalazł żadnego donatysty. Nas interesuje przytoczony urywek listu, w którym św. Augustyn podkreśla, że Piotr był pierwszym biskupem Rzymu i reprezentował cały Kościół w czasie swego wyznania pod Cezareą Filipową. Przytoczona przez niego lista następców św. Piotra dowodzi, że petra, którą jest Piotr i na którym został zbudowany Kościól, nie może być pokonana przez bramy piekielne.

W traktacie poświęconym dyskusji antydonatystycznej De baptismo contra Donatistas Augustyn przytacza prawie dosłownie list św. Cypriana, w którym znajduje się myśl zawarta w wersecie z Mt 16, 18: „et super quem [Petrum] aeddificavit Ecclesiam suam" (por. Mt 16,18), myśl utożsamiająca Piotra ze skałą. W całej tej dyskusji myśl ta wypełnia to dzieło ${ }^{21}$, ale jest również obecna w jego: Contra litteras Petiliani ${ }^{22}$, Ad catholicos de secta Donatistarum ${ }^{23}$, In

${ }^{19}$ Enarratio in PS. 69, 4, NBA 26, 704, thum. J. Sulowski, PSP 39, 227.

${ }^{20}$ Epistola 53, 2, NBA 21, 428, thum. W. Eborowicz: Św. Augustyn, Listy, Pelplin 1991, 327.

${ }^{21}$ Por. De baptismo contra Donatistas, NBA 15/1, tłum. A Żurek: O chrzcie, ŹMT 38, Kraków 2006.

22 Por. Contra litteras Petiliani II 108, CSEL 52, 159: „illa quippe Ecclesia in petra est, sicut Dominus dicit: super hanc petram aedificabo Ecclesiam meam; illi autem in harena aedificant, sicut idem Dominus dicit: qui audit verba mea et non facit ea, simulabo eum viro stulto qui aedificat domum suam super harenam".

${ }^{23}$ Por. Ad catholicos de secta Donatistarum 21, 61, CSEL 52, 309: „, cur ergo vos, ut omittam cetera, non baptizatis post ebriosos luxuriosos invidos, qui regnum Dei non possidebunt et ideo in petra non sunt et, quia in petra non sunt, procul dubio in Ecclesia non 
Johannis Evangelium tractatus ${ }^{24}$, Enarrationes in Psalmos ${ }^{25}$, czy wreszcie w Sermo $358^{26}$. Wszędzie w wymienionych miejscach spotykamy werset Mt 16, 18 sprowadzający się do zdania: ,i na tej skale zbuduję mój Kościół”. Jezus Chrystus zbudował Kościół na Piotrze ${ }^{27}$.

Kiedy Biskup Hippony pisze De consensu Evangelistarum, staje przed nim problem zmiany imienia Szymona na Piotra: porównuje wówczas różne dane Ewangelistów. Analizując Mt 16, 18 i J 1, 42 wykazuje, że nie ma sprzeczności między tymi autorami Ewangelii. Powołując się na słowa Ewangelii według św. Jana: „Ty będziesz nazywał się Kefas, co tłumaczy się Piotr” (J 1, 42) oraz Ewangelii św. Mateusza: „Ty jesteś Piotr” (Mt 16, 18), wnioskuje, że zdarzenie, które opisał św. Jan, było wcześniejsze od wydarzenia pod Cezareą Filipową, które opisał św. Mateusz. Wyjaśnia to w ten sposób, że zmiana imienia Piotra nie dokonała się po wyznaniu w Cezarei, ale wcześniej, już w momencie powołania św. Piotra ${ }^{28}$. To wyjaśnienie raz udzielone przez Biskupa Hippony nie wraca już nigdzie w całym jego dziele, chociaż podkreśla kilka razy tajemnicę zmiany imienia.

Powtórzmy, ze święty Augustyn analizując Mt 16, 18 oraz J 1, 42 podkreśla, że zmiana imienia Piotra dokonała się już w momencie powołania go na apostoła. Imię Piotra pochodzi od petra:

„Skała bowiem nie ma nazwy od Piotra, lecz Piotr od skały, jak Chrystus nie ma imienia od chrześcijanina, lecz chrześcijanin od Chrystusa"29.

Zapewne etymologia słów, będąca ponadto grą wyrazów, zachwycała współczesnych jemu łacinników. Zwrot ten powtarza się u św. Augustyna kilka razy, a wypływa on z jego chrystologicznej myśli, o czym też świadczy następująca wypowiedź:

„Skała jest nazwą pierwotną. Piotr więc pochodzi od «skały», nie skała od «Piotra», jak imię Chrystusa nie od «chrześcijanina», lecz nazwa "chrześcijanin» od Chrystusa" ${ }^{30}$.

deputantur, quia super hanc petram, inquit, aedificabo Ecclesiam meam, et nos vultis ut baptizemus post haereticos, qui inter easdem spinas regnum Dei non possessuras enumerati sunt et quibus similiter sacramenta insunt, quando eadem sunt, sed non prosunt, quia, cum illa recta sint, ipsi perversi sunt?".

${ }^{24}$ Por. In Johannis Evangelium tractatus 7, 14, NBA 24/1, 172.

25 Por. Enarratio in Ps. 60, 3, NBA 26, 326.

26 Por. Sermo 358, 5, NBA 34, 4.

27 De baptismo contra Donatistas VI 24, 43, NBA 15/1, 524.

28 Por. De consensu Evangelistarum II 17, 34, NBA 10/1, 130.

29 In Johannis Evangelium tractatus 124, 5, NBA 24/2, 1618: „Non enim a Petro petra, sed Petrus a petra, sicut non Christus a christiano, sed christianus a Christo vocatur”.

30 Sermo 76, 1, NBA 30/1, 514: „Petra enim principale nomen est. Ideo Petrus a petra, non petra a Petro; quomodo non a Christiano Christus, sed a Christo Christianus vocatur". 
W siódmej Homilii do Ewangelii św. Jana św. Augustyn jakby się wahał nad odpowiedzią, kto jest Piotrem, pisze bowiem:

„Piotr więc pochodzi od skały, skała zaś jest Kościołem, a zatem w imieniu Piotra jest przedstawiony Kościół” ${ }^{\prime 3}$.

W kontekście urywka Mt 16, 13-23 Piotr przedstawiał z woli Chrystusa cały Kościół, któremu została powierzona władza kluczy pod Cezareą Filipową. Piotr odbierał ją wówczas nie dla siebie samego, ale jako wzór i przedstawiciel całego Kościoła. Jest nim wówczas, kiedy Jezus stawia mu pytanie o miłość ${ }^{32}$, kiedy przyjmuje do Kościoła poganina Korneliusza ${ }^{33}$, kiedy został nazwany przez Pana szatanem ${ }^{34}$ i kiedy upadł, ale potem więcej kochał Chrystusa niż inni apostołowie ${ }^{35}$. Piotr jest więc reprezentantem wszystkich, zarówno silnych jak i słabych, członków Kościoła.

Myśl tę rozwija Augustyn także w Enarrationes in Psalmos, kiedy wyjaśnia Psalm 54, 5, i Psalm 30, 2, a więc dwa wiersze wyrażające skargę człowieka porzuconego. Według kaznodziei wersety te wyrażają utrapienie tych, którzy są zatroskani o zbawienie braci. Często ogarniająca wątpliwość tych, którzy pragną miłować swoich nieprzyjaciół, zestawia z lękiem Piotra w czasie burzy na morzu:

„Chrystus chodził bez lęku po morzu, ponieważ z jego serca nie można było usunąć miłości do nieprzyjaciół [...]. Piotr też chciał chodzić. Chrystus jako głowa (caput), Piotr niczym ciało (corpus). Ponieważ «na tej skale», rzekł, «zbuduję mój Kościół» (Mt 16, 16)" ${ }^{36}$.

Piotr otrzymał polecenie przyjścia i szedł, ale nie o własnych siłach, bo kiedy wskutek silnego wiatru zaczął tonąć, szukał skutecznego ratunku u Pana, bo Chrystus jest głową, Piotr - ciałem, bo na tej skale, czyli na Piotrze, Chrystus zbuduje swój Kościół”.

W komentarzu zaś do Psalmu 30 św. Augustyn mówi m.in. o Piotrze, który przedstawiał Kościół, mający włączać narody w swoją wspólnotę. Piotr usłyszał:

„Odezwał się do Piotra: «Zabijaj i jedz» (Dz 10, 13). O Kościele (to znaczy

o Piotrze, bo na tej skale zbuduję mój Kościół) «zabijaj i jedz». Najpierw zabijaj,

a potem jedz; zabij, czym są oni, a uczyń, czym sam jesteś ${ }^{37}$.

31 In Johannis Evangelium tractatus 7, 14, NBA 24/1, 172: „Petrus autem a petra, petra vero Ecclesia; ergo in Petri nomine figurata est Ecclesia".

32 Por. tamze 47, 2, NBA 24/1, 932.

33 Por. Sermo 4, 19, NBA 29, 50; Sermo 149, 5, NBA 31/1, 428 .

34 Por. Sermo 76,3, NBA 30/1, 516.

35 Por. In Johannis Evangelium tractatus 66, 2, NBA 24/2, 1148 i 1150; 124, 4-6, NBA 24/2, $1612-1622$.

36 Enarratio in Psalmum 54, 5, NBA 26, 84

37 Enarratio in Psalmum 30 (2), 5, NBA 25, 470: „Et ait Petro: «Macta et manduca». O Ecclesia (hoc est Petre, quia super hanc petram aedificabo Ecclesiam meam) «macta et manduca»; prius macta, et sic manduca; occide quod sunt, et fac quod es". 
Kiedy spuszczono Piotrowi z nieba naczynie pełne najrozmaitszych zwierząt czworonożnych, wężów i gadów, które symbolizowały wszystkie narody, Pan w ten sposób, wyjaśnia św. Augustyn, zapowiadał Kościół, którego Apostoł był przedstawicielem. Na nim, na Piotrze, jako na skale zbuduje swój Kościół, który będzie przemieniał świat, bo to właśnie oznacza zwrot: „zabijaj i jedz”, czyli niszcz w nich to, co złe, a uczyń ich przez głoszenie Ewangelii tym, czym sam jesteś.

3. Petra - Kościól. „Petra” u św. Augustyna oznacza nie tylko Chrystusa oraz Piotra jako przedstawiciela Kościoła i uosabiającego Kościół, ale też sam Kościół. W Komentarzu do Ewangelii św. Jana omawiając pochodzenie imienia Piotra i powód zmiany imienia „Szymon” na imię „Piotr”, pisze:

„Piotr bowiem pochodzi od skały, skałą zaś jest Kościół; zatem w imieniu Piotra jest przedstawiony Kościół” ${ }^{38}$.

Bezpieczny jest budujący na skale, a jest nim ten, który słucha słów Pana i je wypełnia. Jeśli ktoś słyszy słowa Pana, ale ich nie wypełnia, buduje na piasku i nie należy do wielkiego imienia Piotra, na które Chrystus zwrócił uwagę. Bóg chciał, by Piotr był wpierw inaczej nazwany, aby sama zmiana imienia zwróciła uwagę na żywotność znaku.

Omawiając problemy Pentateuchu, między innymi laskę i Boże miłosierdzie, Biskup Hippony zastanawia się, co oznacza zwrot: „Oto miejsce obok mnie" (Wj 33, 21), skoro Pan Bóg jest wszędzie obecny. Wyjaśnia więc, że tymi słowami Kościół wskazuje niejako na swoją świątynię: „i staniesz na skale", ponieważ Pan na skale zbuduje swój Kościół, dokona tego po swoim przejściu, czyli po męce i zmartwychwstaniu. Lud wierny stanie na skale, którą jest Kościót ${ }^{39}$.

W Annotationes in Job z 399 r., św. Augustyn przypominając, że „skałą był Chrystus", pisze, że także cały Kościół należy rozumieć jako skałę ze względu na Szymona, którego z tego powodu Pan nazwał Piotrem, a szczyt skały jest głową Kościoła:

„Et quia petra etiam tota Ecclesia bene intellegitur, propter etiam Simonem, qui ob hoc a Domino Petrus appellatus est (por. Mc 3,16), summitas petrae est caput Ecclesiae" ${ }^{, 40}$.

Widać tu wyraźny związek terminu petra z osobą Piotra, któremu Chrystus zmienił imię ze względu na założony przez siebie Kościół, którego bramy

38 In Johannis Evangelium tractatus 7, 14, NBA 24/1, 172: „Petrus autem a petra, petra vero Ecclesia; ergo in Petri nomine figurata est Ecclesia", tłum. W. Szołdrski, PSP 15/1, 123.

39 Por. Quaestiones in Heptateuchum II 154, 6, NBA 11/1, 726; por. tłum. J. Sulowskiego: Problemy Pentateuchu, PSP 46, 158.

40 Annotationes in Job 39, NBA 10/3, 188. 
piekielne nie przemogą (por. Mt 16, 18). Głową Kościoła, szczytem skały (summitas petrae), jest Chrystus.

4. Petra - fides. Święty Augustyn utożsamia petra także z fides. W De Trinitate pisze:

"«Sed dum peregrinamur a Domino et per fidem ambulamus non per speciem», posteriora Christi, hoc est carnem, per ipsam fidem videre debemus, id est in solido fidei fundamento stantes quod significat petra, et eam de tali tutissima specula intuentes, in catholica scilicet Ecclesia de qua dictum est: «Et super hanc petram aedificabo Ecclesiam meam»" (Mt 16, 18) ${ }^{, 41}$.

W tym fragmencie nie chodzi bezpośrednio o samego Piotra, ale o Kościół katolicki, który stoi na trwałym fundamencie wiary, a którego symbolem jest skała. Jest to wiara we wcielenie i zmartwychwstanie Chrystusa:

„Tym pewniej bowiem miłujemy oblicze Chrystusowe, które ujrzeć pragniemy, im lepiej w człowieczeństwie Jego poznajemy, jak Chrystus pierwszy nas umiłował”42.

W siódmej homilii na Ewangelię św. Jana (1, 34-51) Biskup Hippony przytacza wyznanie Natanaela: „Rabbi, Ty jesteś Synem Boga, Ty jesteś królem Izraela" (J 1, 49) i porównuje je z wyznaniem św. Piotra (Mt 16, 16). Piotr usłyszał wtedy z ust Pana: „Błogosławiony jesteś, Szymonie, synu Jony. Albowiem nie objawiły ci tego ciało i krew, lecz Ojciec mój, który jest w niebie" (Mt 16, 17). Św. Augustyn przypomina, że wtedy Jezus nazwał go skałą (petra) i fundamentem (firmamentum) Kościoła dzięki wierze (fides). Biskup wyjaśnia, że wyznanie Piotra w bóstwo Chrystusa, dokonało się dzięki objawieniu, jakie Apostoł otrzymał od Ojca Niebieskiego. Św. Augustyn nie przytoczył wiersza Mt 16, 18, ale skupił się na utożsamieniu trzech terminów: petra - firmamentum - fides ${ }^{43}$.

W homilii dziesiątej na I List św. Jana, analizując werset: „Każdy, kto wierzy, że Jezus jest Chrystusem, z Boga się narodził" (1J 5, 1), odwołuje się do Mt 16, 18, głosząc:

„Videte quae laudes prosequantur hanc fidem: «Tu es Petrus et super hanc petram aedificabo Ecclesiam meam». Quid est: «Super hanc petram aedificabo Ecclesiam meam»? Super hanc fidem, super id quod dictum est: «Tu es Christus Filius Dei vivi». "Super hanc petram» inquit, «fundabo Ecclesiam meam». Magna laus!"44.

${ }^{41}$ De Trinitate II 17, 28, NBA 4, 114, tłum. M. Stokowska, POK 25, 144: „Lecz póki pielgrzymujemy z dala od Pana, i póki w wierze a nie w widzeniu (2Kor 5, 6-7), «plecy» Chrystusa, czyli ciało jego przez wiarę oglądać musimy. To znaczy stojąc na mocnym fundamencie wiary, którego symbolem jest skała, mamy nań patrzeć z tej bezpiecznej strażnicy katolickiego Kościoła, o którym powiedziano: «na tej skale zbuduję Kościół mój» (Mt, 16, 18)".

42 Tamże.

43 Por. In Johannis Evangelium tractatus 7, 20, NBA 24/1, 180.

44 In Ioannis Epistolam ad Parthos tractatus 10, 1, NBA 24/, 2, 1834, tłum. W. Szołdrski W. Kania, PSP 15/2, 374: „Patrzcie, jaką pochwałę otrzymuje ta wiara Piotra: «Ty jesteś Piotr, a na 
Ta wielka pochwała, którą podziwia św. Augustyn, to obietnica założenia Kościoła na wierze św. Piotra. Biskup uściśla: „na tej wierze, którą wyznałeś: «Ty jesteś Chrystusem Synem Boga żywego»", a więc jest to wiara nie tylko w znaczeniu subiektywnym jako akt cnoty wiary Apostoła, ale przede wszystkim obiektywna, zawierająca treść wyznania wiary św. Piotra ${ }^{45}$. Widać tu wyraźnie, że Biskup Hippony upatruje skałę (petra) - fundament założenia Kościoła w bóstwie Chrystusa, wyznanym przez Apostoła Piotra pod Cezareą Filipową.

Z przeprowadzonej analizy tekstów wynika, że termin petra przyjmuje u św. Augustyna, w zależności od kontekstu i okoliczności jego przekazu, różne znaczenia: Chrystus, Piotr, Kościół, wiara i łaska. Kiedy odnosi petra do Apostoła Piotra, to łączy ją z jego wiarą. Na tej wierze Chrystus zbuduje swój Kościół, „a bramy piekielne go nie przemogą”. Chrystus jest jedyną skałą, Piotr Apostoł zaś jest Kościołem:

„Czym przeto jest we właściwym znaczeniu Kościół w Chrystusie, tym jest symbolicznie Piotr w skale; w tym symbolicznym znaczeniu należy rozumieć Chrystusa jako skałę, a Piotra jako Kościół”46.

Na tym fundamencie Kościół będzie trwał po wszystkie wieki.

Biskup Hippony często podkreślał, że głową Kościoła i jego pasterzem jest Chrystus. Chrystus jest też pierwszorzędnym i jedynym fundamentem Kościoła, Piotr zaś, będąc drugorzędnym, swoją moc i władze czerpie od Chrystusa. Zmiana imienia po wyznaniu bóstwa Chrystusa wiązała się z zadaniem, jakie Piotr miał w przyszłości spełnić, a mianowicie z przekazaniem wszystkim ludziom tego, co otrzymał od Chrystusa, a otrzymał cały Kościół. On też reprezentuje jedność Kościoła. Pełni tę rolę ze względu na prymat, jaki miał wśród apostołów i uczniów Chrystusa, ale to jest już oddzielne zagadnienie.

tej skale zbuduję mój Kościół» (Mt 16, 14-18). Co znaczą te słowa: «Na tej skale zbuduję mój Kościół»? Na tej wierze, którą wyznałeś: «Ty jesteś Chrystusem, Synem Boga żywego». «Na tej skale» - powiedział - «zbuduję mój Kościół». Jaka wielka pochwała!”.

45 Por. E. Fraenkel, Zur Geschichte des Wortes „Fides”, ,Rheinisches Museum für Philologie” 71 (1916) 187-199; A. Meillet, Latin credo et fides, „Memoire de la Société de Linguistique de Paris” 22 (1921) 215-218; R. Heinze, Fides, „Hermes” 64 (1929) 140 -166; W. Granat, Teologiczna wiara, nadzieja i miłość, Lublin 1960.

46 In Johannis Evangelium tractatus 124, 5, NBA 24/2, 1618: „quod est enim per proprietatem in Christo Ecclesia, hoc est per significationem Petrus in petra; qua significatione intellegitur Christus petra, Petrus Ecclesia”, tłum. W. Szołdrski, PSP 15/2, 374 
QUOMODO A SANCTO AUGUSTINO „PETRA” IN Mth 16, 18 EXPLICATA SIT

(Argumentum)

Ex analysi operum Sancti Augustini evenit, ut terminus petra varias significationes acceperit, quae sunt: Christus, Petrus, Ecclesia, fides et gratia. Petra Petrum et eius fidem significat. Super hanc fidem Petri Christus Ecclesiam suam aedificat, quam portae inferi non vincent. Christus est unica petra, Petrus autem, qui alterum locum obtinet, est Ecclesia. „Quod est enim per proprietatem in Christo Ecclesia, hoc est per significationem Petrus in petra; qua significatione intellegitur Christus petra, Petrus Ecclesia". Quo in fundamento Ecclesia existet in perpetuum. 